Ewa Baruk-Dzięcioł

Uniwersytet Warmińsko-Mazurski w Olsztynie

\title{
Nadużywanie alkoholu przez członka rodziny jako czynnik modelujący językowy obraz świata osób dorosłych
}

\section{Alcohol abuse by a family member as a factor modelling the linguistic image of the adult world}

\begin{abstract}
Abstrakt
Nadużywanie alkoholu przez członka rodziny jest jednym z czynników sprzyjających powstawaniu jej dysfunkcji. Obecność tego problemu w środowisku rodzinnym wpływa deformująco na sposób postrzegania i interpretowania otaczającej rzeczywistości przez pozostałych jej członków. Stąd kształtujący się w ich świadomości obraz własnej osoby i otaczającego świata jest często nieadekwatny i zafałszowany.

Celem zrealizowanych badań było określenie zawartości zarówno językowego prototypu nałogu, jak i językowego prototypu alkoholizmu u osób dorosłych, w których rodzinie obecny jest problem nadużywania alkoholu. Nasuwa się więc pytanie, czy nadużywanie alkoholu przez członka rodziny może warunkować zawartość językowego prototypu nałogu i językowego prototypu alkoholizmu, które ukształtowały się w świadomości osób dorosłych pochodzących z rodzin obarczonych tym problemem?

Odpowiedzi na to pytanie można szukać w wynikach eksperymentu asocjacyjnego przeprowadzonego wśród osób wywodzących się z rodzin dotkniętych problemem nadużywania alkoholu oraz bez tego problemu z wykorzystaniem słów-bodźców nałóg i alkoholizm.

Udało się zauważyć, że językowy prototyp nałogu jest zbieżny zarówno ze względu na zakres znaczeniowy u respondentek $z$ poszczególnych grup, jak i pozycje rangowe zajmowane przez asocjacje go wypełniające. Jednakże konkretne skojarzenia osiągnęły odmienną częstość użycia w poszczególnych grupach respondentek. Wskazuje to na różne odczuwanie przez nie istotności poszczególnych elementów w językowym obrazie nałogu. Okazało się też, że językowy prototyp alkoholizmu ma zbliżony zakres znaczeniowy. Jednakże asocjacje go budujące osiągnęły nie tylko odmienną częstość użycia, ale i zajęły odmienne pozycje rangowe u respondentek z poszczególnych grup.

Podsumowując, można stwierdzić, że nałóg i alkoholizm są takimi elementami językowego obrazu świata, które są uwarunkowane przez oddziaływania społeczno-kulturowe i edukacyjne.
\end{abstract} cjacyjny

Słowa kluczowe: językowy obraz świata, rodzina, nadużywanie alkoholu, eksperyment aso-

\section{Wprowadzenie}

Nadużywanie alkoholu przez członka rodziny jest jednym z istotnych czynników sprzyjających powstawaniu dysfunkcji środowiska rodzinnego (Kałdon, 2015, s. 95; Zalas, 2011, s. 285; Miśkowicz, 2013, s. 117-118; Młyński, 2012, s. 133). Dzieje się tak z tego względu, że w rodzinie dotkniętej problemem alkoholowym 
brakuje właściwych wzorów kontaktów interpersonalnych, często natomiast obecna jest wzajemna wrogość oraz konflikty połączone z agresją i przemocą (Cudak, 2011, s. 11-12; Kałdon, 2015, s. 97; Zalas, 2011, s. 292). Stąd osoby wywodzące się z rodzin dotkniętych problemem nadużywania alkoholu często przejawiają zachowania i stosują modele relacji interpersonalnych, które są efektem traumatycznych doświadczeń życia rodzinnego (Kałdon, 2015, s. 102; Zalas, 2011, s. 294).

W rodzinie dotkniętej problemem nadużywania alkoholu istotnemu zaburzeniu ulegają sposoby percypowania i interpretowania rzeczywistości przez jej członków. Osoby wywodzące się z takich rodzin posiadają więc często nieadekwatny i zafałszowany obraz nie tylko własnych doświadczeń i odczuć, ale również obraz otaczającego świata (Kałdon, 2015, s. 97-98). Stąd celem zrealizowanych badań empirycznych było określenie zawartości zarówno językowego prototypu ${ }^{1}$ nałogu, jak i językowego prototypu alkoholizmu u osób dorosłych, w których rodzinie jest obecny problem nadużywania alkoholu. Rodzi się tutaj pytanie, czy nadużywanie alkoholu przez członka rodziny może modelować zawartość językowego prototypu nałogu i językowego prototypu alkoholizmu, które ukształtowały się w świadomości dorosłych członków ich rodzin? Prawdopodobne wydaje się to, że obecność w środowisku rodzinnym problemu alkoholowego jest czynnikiem modelującym zawartość zarówno prototypu nałogu, jak i prototypu alkoholizmu, które powstały w świadomości osób dorosłych, a zostały wyrażone na płaszczyźnie ich języka.

Obraz świata jest systemem wiedzy o świecie, który kształtuje się w procesie gromadzenia i interpretowania informacji pochodzących nie tylko z przekazów społeczno-kulturowych, ale również z bezpośredniego doświadczenia poznawczego (Rudkowska, 1998, s. 312). Językowy obraz świata jest zestawem sądów, które są utrwalone poprzez język i szczególnie obecne w znaczeniach wyrazów (Bartmiński, 2012, s. 66). Stanowi on „potoczną interpretację rzeczywistości z punktu widzenia przeciętnego użytkownika języka, oddaje jego mentalność, odpowiada jego punktowi widzenia i jego potrzebom" (Bartmiński, 2012, s. 14). Istotne jest również to, że „język odzwierciedla hierarchie wartości oraz systemy znaczeń, umożliwia dostęp do świata i poznanie go w sposób już z góry określony, bo zawiera model świata (światów) i sprawia, że model ten (modele) kształtuje [...] widzenie świata (światów) i wpływa na jego (ich) obraz. Język oddziałuje na zachowania społeczne, organizując i regulując je oraz sterując nimi [...]. Język służy wreszcie do weryfikowania i kodyfikowania treści kulturowych" (Anusiewicz, Dąbrowska i Fleischer, 2000, s. 20).

J. Ożdżyński jest zdania, iż rola języka i kultury nie ogranicza się jedynie do „fotograficznego odbicia” rzeczywistości. Ich zadaniem jest modelowanie, współtworzenie i projektowanie świata zgodnie z możliwościami percepcyjnymi człowieka (Ożdżyński, 1995, s. 32). Stąd językowy obraz świata można traktować jako sposób wniesienia do języka nie tylko doświadczenia poznawczego, ale również wyobrażanej i przeżytej przez jego użytkowników rzeczywistości (Maćkiewicz, 1999, s. 193-194).

1 R. Jedliński uważa, iż „prototyp obejmuje [...] reprezentację charakterystycznych cech posiadanych przez desygnaty czy egzemplarze pojęcia" (Jedliński, 2000, s. 44-45). 


\section{Z badań nad językowym obrazem nałogu i alkoholizmu}

Przywołane badania zostały przeprowadzone w marcu 2019 r. z wykorzystaniem eksperymentu asocjacyjnego. Jest to jedna z metod umożliwiających rekonstrukcję językowego obrazu świata respondentów. Dzięki niemu „istnieje możliwość dotarcia do konceptualnych systemów badanych osób poprzez analizę materiału językowego, uzyskanego w wyniku badań” (Grabska, 2000, s. 335).

Wyróżnia się dwa typy eksperymentu asocjacyjnego. Pierwszy z nich to swobodny eksperyment asocjacyjny, który ma charakter otwarty. Zadaniem respondentów jest podanie tych reakcji werbalnych, które skojarzą się im z zaprezentowanym słowem-bodźcem. Kolejnym typem eksperymentu asocjacyjnego jest kierowany eksperyment asocjacyjny, w którym reakcje słowne respondentów precyzuje dodatkowa instrukcja.

Metoda eksperymentu asocjacyjnego łączy się z czterodzielną klasyfikacją technik stosowanych w jego obrębie. Należy do nich kojarzenie swobodne jednorazowe, kojarzenie swobodne ciągłe, a także kojarzenie kierowane jednorazowe i kojarzenie kierowane ciągłe. Kojarzenie swobodne jednorazowe polega na wymienieniu przez respondentów dowolnego słowa, które skojarzy im się z prezentowanym bodźcem werbalnym, przy czym istotny jest czas tej reakcji. Kojarzenie jednorazowe kierowane podobne jest do poprzedniego, ale zawiera instrukcję precyzującą reakcję słowną osoby badanej. Kojarzenie ciągłe swobodne dotyczy podania przez respondenta ciągu dowolnych słów w określonym czasie. Z kolei przy kojarzeniu ciągłym kierowanym ten łańcuch reakcji werbalnych ogranicza konkretna instrukcja (Woodworth i Schlosberg, 1963, s. 81-84).

Do przeprowadzenia badań zastosowano eksperyment skojarzeniowy w wersji swobodnej ciągłej. Słowami-bodźcami były nałóg i alkoholizm. Badania miały charakter pisemny, a czas ich trwania wynosił około 10 minut. Narzędzie badawcze skonstruowano w ten sposób, że respondenci musieli wymienić najpierw swoje skojarzenia ze słowem nałóg, dopiero później był eksponowany kolejny bodziec werbalny - alkoholizm. Następnie zebrano informacje o ewentualnym nadużywaniu alkoholu przez członków ich rodziny (m.in. przez rodziców, dziadków lub dalszych krewnych i powinowatych).

Badania zrealizowano wśród studentek pedagogicznych kierunków studiów. Udało się wyodrębnić wśród nich grupę osób, których rodziny nie były dotknięte problemem nadużywania alkoholu (B) oraz grupę respondentek, w których rodzinie pojawiły się osoby go nadużywające (A). Badaniami objęto łącznie 92 osoby, w tym z rodzin z dotkniętych problemem nadużywania alkoholu - $44(47,83 \%$ wszystkich respondentek), zaś z rodzin bez takiego problemu - 48 (52,17\%). Uzyskanie równolicznych grup - w warunkach akademickich - okazało się trudne do zrealizowania.

Istotną kwestią była weryfikacja założenia o możliwości istnienia związku pomiędzy zawartością językowego prototypu nałogu i językowego prototypu alkoholizmu respondentek a faktem nadużywania alkoholu przez członków ich rodzin.

Metodą statystyczną, która została wykorzystana przy analizie materiału badawczego, było obliczenie średniej arytmetycznej asocjacji wymienionych przez 
przeciętną respondentkę z każdej z grup. Dokonano tego oddzielnie w odniesieniu do materiału leksykalnego uzyskanego w związku z ekspozycją poszczególnych słów bodźcowych. Następnie obliczono wartość wskaźnika różnicującego (Wr) te średnie.

W tabeli 1 zaprezentowano dane liczbowe charakteryzujące otrzymany materiał badawczy.

Tabela 1. Zestawienie danych liczbowych charakteryzujących uzyskany materiał leksykalny

\begin{tabular}{|c|c|c|c|c|c|c|}
\hline \multirow{2}{*}{$\begin{array}{c}\text { grupa } \\
\text { respondentów }\end{array}$} & \multirow{2}{*}{$\begin{array}{c}\text { liczba } \\
\text { osób }\end{array}$} & \multicolumn{2}{|c|}{ liczba asocjacji } & \multicolumn{2}{|c|}{ średnia arytmetyczna asocjacji } \\
\cline { 3 - 7 } & nałóg & alkoholizm & nałóg & alkoholizm & $\mathrm{Wr}$ \\
\hline B & 48 & 320 & 288 & 6,67 & 6,00 & 0,67 \\
\hline A & 44 & 264 & 260 & 6,00 & 5,91 & 0,09 \\
\hline Razem & 92 & 584 & 548 & $\mathrm{Wr}=0,67$ & $\mathrm{Wr}=0,09$ & $\mathrm{Wr}=0,58$ \\
\hline
\end{tabular}

Źródło: opracowanie własne.

Dane ujęte w tabeli nr 1 pokazują, że w tej części eksperymentu skojarzeniowego, gdzie słowem bodźcowym był nałóg, przeciętna respondentka z rodziny dotkniętej problemem alkoholowym wymieniła o 0,67 asocjacji mniej niż osoba z rodziny bez takiego problemu. Podobnie stało się przy ekspozycji słowa-bodźca alkoholizm, gdzie przeciętna osoba z rodziny bez problemu alkoholowego wśród jej członków wymieniła zaledwie o 0,09 skojarzenia więcej niż respondentka z rodziny, w której pojawił się problem jego nadużywania. Tak więc każdorazowo przeciętna osoba z rodziny bez problemu alkoholowego wymieniała nieznacznie więcej reakcji werbalnych w związku z poszczególnymi słowami-bodźcami.

Z kolei w odniesieniu do wartości wskaźnika różnicującego średnie arytmetyczne asocjacji przypadających na przeciętną respondentkę z każdej z grup w aspekcie danych słów bodźcowych także zaznaczają się pewne prawidłowości. Okazało się, że przeciętna osoba wywodząca się z rodziny dotkniętej problemem alkoholowym wymieniła jedynie o 0,09 reakcji werbalnej więcej przy prezentacji bodźca nałóg niż alkoholizm. Również przeciętna respondentka pochodząca z rodziny bez problemu alkoholowego podała o 0,67 asocjacji więcej z związku z słowem-bodźcem nałóg niż ze słowem-bodźcem alkoholizm. Tak więc zarówno respondentki z rodzin dotkniętych problemem nadużywania alkoholu, jak i wywodzące się z rodzin bez takiego problemu, wymieniły nieznacznie więcej skojarzeń w związku z ekspozycją słowa bodźcowego nałóg niż bodźca werbalnego alkoholizm.

Te niewielkie wartości wskaźnika różnicującego pokazują, że oba bodźce werbalne aktywizują emocjonalnie w bardzo zbliżonym zakresie zarówno respondentki z poszczególnych grup, jak i respondentki w obrębie każdej grupy w aspekcie danego słowa bodźcowego. Wynika stąd, że obecność w środowisku rodzinnym osoby nadużywającej alkoholu nie jest czynnikiem, który w istotny sposób warunkuje ilość reakcji werbalnych wymienianych przeciętnie przez osoby objęte badaniami. 
Kolejną płaszczyzną opracowania uzyskanego materiału badawczego była analiza jego struktury rangowej. Wśród skojarzeń o istotnej frekwencji wyłoniono dwa bloki, które budują zarówno językowy prototyp nałogu, jak i językowy prototyp alkoholizmu. Podstawą ich klasyfikacji stała się osiągnięta przez nie częstość użycia (Cu), która wskazuje na to, jaka część objętych badaniami osób wymieniła konkretne skojarzenie.

Do pierwszego z zasygnalizowanych bloków włączono te skojarzenia, które podało więcej niż $50 \%$ respondentek (Kurcz, 2000, s. 111). Budują one rdzeń prototypu zasygnalizowanych przez słowa-bodźce elementów rzeczywistości. Z kolei do drugiego bloku zaliczono te asocjacje, które osiągnęły próg 20,00\% częstości użycia i zostały zarazem wymienione przez mniej niż 50,00 \% objętych badaniami osób.

W tabeli 2 zaprezentowano zawartość językowego prototypu nałogu u respondentek z poszczególnych grup.

Tabela 2. Zestawienie skojarzeń zakwalifikowanych do językowego prototypu nałogu u respondentek

\begin{tabular}{|c|c|c|c|c|c|}
\hline \multicolumn{7}{|c|}{ słowo-hasło nałóg } \\
\hline \multirow{2}{*}{ asocjacja } & \multicolumn{2}{|c|}{ pozycja rangowa } & \multicolumn{3}{c|}{ Cu w \% } \\
\cline { 2 - 6 } & grupa B & grupa A & grupa B & grupa A & Wr \\
\hline uzależnienie & I & I & 83,33 & 72,27 & 11,06 \\
\hline alkohol & II & II & 66,67 & 45,45 & 21,22 \\
\hline narkotyki & III & III & 62,50 & 36,36 & 26,14 \\
\hline papierosy & IV & IV & 50,00 & 27,27 & 22,73 \\
\hline problemy & V & IV & 25,00 & 27,27 & 2,27 \\
\hline używki & VI & VIII & 20,83 & 6,82 & 14,01 \\
\hline choroba & VIII & IV & 8,33 & 27,27 & 18,94 \\
\hline
\end{tabular}

Źródło: opracowanie własne.

Istotną kwestią, na którą warto zwrócić uwagę, analizując materiał leksykalny uzyskany w związku z ekspozycją słowa-bodźca nałóg i zaprezentowany w tabeli 2, jest zakres jego językowego prototypu, szczególnie zaś jego rdzenia. Okazało się, że na pierwszej pozycji rangowej - wśród asocjacji respondentek z obu grup - znalazło się skojarzenie „uzależnienie”. Można więc uznać je za emblemat ich językowego obrazu tego aspektu rzeczywistości.

Znamienne, że w obrębie materiału badawczego otrzymanego od osób z poszczególnych grup odmienna liczba skojarzeń została włączona do rdzenia językowego prototypu nałogu. I tak wśród reakcji werbalnych respondentek z rodzin, w których nie jest nadużywany alkohol, próg częstości użycia wynoszący $50 \%$ osiągnęły cztery asocjacje. Natomiast respondentki wywodzące się z rodzin 
obarczonych tym problemem podały zaledwie jedno skojarzenie spełniające wspomniany warunek. Odmienną sytuację można natomiast zauważyć w odniesieniu do reakcji werbalnych, które zostały wymienione przez mniej niż 50,00\% objętych badaniami osób i jednocześnie przez przynajmniej $20 \%$ spośród nich. Respondentki pochodzące z rodzin dotkniętych problemem alkoholowym podały pięć asocjacji tego typu, natomiast respondentki z rodzin bez niego - wymieniały jedynie dwie. Jednak finalnie osoby z obu grup wymieniły jednakową ilość asocjacji, które zostały zakwalifikowane do ich językowego prototypu nałogu.

Warto zwrócić uwagę na fakt, że na szczycie list rangowych dla słowa-bodźca nałóg wśród asocjacji respondentek z poszczególnych grup pojawiły się cztery skojarzenia pokrywające się pod względem znaczeniowym. Są to: „uzależnienie”, „alkohol”, „narkotyki” oraz „papierosy”. Natomiast pozycje rangowe kolejnych asocjacji w obrębie językowego prototypu nałogu u respondentek z poszczególnych grup krzyżują się lub ulęgają nieznacznym przesunięciom, także poza jego obręb.

Godny uwagi jest zakres znaczeniowy asocjacji tworzących językowy prototyp nałogu. Dotyczą one nie tylko jego natury („uzależnienie” i „choroba” - jedynie u respondentek $z$ rodzin dotkniętych problemem nadużywania alkoholu ${ }^{2}$ ) oraz rodzajów substancji uzależniających („alkohol”, „narkotyki”, „papierosy”, „używki" - skojarzenie to pojawiło się tylko u osób pochodzących z rodzin, w których nie pojawił się problem nadużywania alkoholu³), ale również jego konsekwencji („problemy”).

Interesująca jest wartość wskaźnika różnicującego częstość użycia poszczególnych asocjacji wymienionych przez respondentki z obu grup. Świadczy ona bowiem o odmiennym odczuwaniu przez nie istotności konkretnych aspektów językowego obrazu nałogu. I tak chociaż skojarzenia „uzależnienie”, „alkohol”, „narkotyki” oraz „papierosy” zajęły w poszczególnych grupach zbieżne pozycje rangowe (cztery początkowe), to jednak osoby wywodzące się z rodzin bez problemu alkoholowego wymieniały je znacznie częściej niż respondentki pochodzące z rodzin dotkniętych tym problemem. Wartość wskaźnika różnicującego częstość ich użycia oscyluje pomiędzy 11,06 a 26,14 punktu procentowego.

Zasygnalizowana sytuacja prowadzi do dwóch spostrzeżeń. Po pierwsze - zawartość językowego prototypu nałogu wydaje się być uwarunkowana przez wpływy społeczno-kulturowe oraz oddziaływania edukacyjne. Po drugie - wartości wskaźnika różnicującego częstość użycia skojarzeń wypełniających jego prototyp wydają się wskazywać na fakt, że słowo bodźcowe wpłynęło hamująco na proces kojarzenia (wydobywania poszczególnych asocjacji z zasobu słownika umysłowego ${ }^{4}$ ) u osób wywodzących się z rodzin, w których jest nadużywany alkohol. Może to wiązać się z działaniem psychologicznych mechanizmów obronnych

2 Skojarzenie „choroba” pojawiło się w grupie respondentek z rodzin bez problemu alkoholowego z częstością użycia wynoszącą 8,33\% i tym samym nie znalazło się w obrębie ich językowego prototypu nałogu.

3 Asocjacja „używki” osiągnęła w grupie osób z rodzin dotkniętych problemem alkoholowym częstość użycia wynoszącą zaledwie 6,82\% i w związku z tym nie znalazła się w obrębie ich językowego prototypu nałogu.

4 Według I. Kurcz słownik umysłowy jest intuicyjną wiedzą na temat wyrazów określonego języka etnicznego, którą posiadają jego użytkownicy (Kurcz, 2000, s. 106). 
- w szczególności zaś wypierania ze świadomości faktu borykania się w środowisku rodzinnym z problemem nadużywania alkoholu.

Warte odnotowania jest także to, że skojarzenie „choroba” - lokujące się w obrębie językowego prototypu nałogu u osób pochodzących z rodzin z problemem alkoholowym - nie znalazło się w jego obrębie u pozostałych respondentek. Podobna sytuacja zachodzi w odniesieniu do skojarzenia „używki”. Jednak w tym wypadku częściej wymieniały je osoby, w których rodzinach nikt nie nadużywa alkoholu. Znalazło się więc ono jedynie w obrębie językowego prototypu nałogu osób z tej grupy respondentek. Źródła tej sytuacji można upatrywać w zdobytym przez te osoby indywidualnym doświadczeniu poznawczym w środowisku rodzinnym.

Podsumowując, konfiguracja asocjacji tworzących językowy prototyp nałogu u respondentek z poszczególnych grup świadczy o tym, że jest on silnie uwarunkowany przez oddziaływania społeczno-kulturowe i edukacyjne. Z kolei indywidualne doświadczenie egzystencjalne respondentek ma swoje odbicie na płaszczyźnie częstości użyć osiągniętej przez poszczególne asocjacje. Wskazuje ona na odmienne odczuwanie istotności konkretnych elementów w obrazie nałogu w ich świadomości, a słów - w jego językowym obrazie.

Jak natomiast kształtuje się prototyp alkoholizmu u respondentek z poszczególnych grup, który został wyrażony poprzez ich język?

W tabeli 3 zawarte jest zestawienie skojarzeń, które zostały włączone do językowego prototypu alkoholizmu u osób pochodzących z rodzin obarczonych problemem alkoholowym oraz z rodzin bez problemu jego nadużywania.

Tabela 3. Zestawienie skojarzeń zakwalifikowanych do językowego prototypu alkoholizmu u respondentek

\begin{tabular}{|c|c|c|c|c|c|}
\hline \multirow{2}{*}{ asocjacja } & pozycja rangowa & \multicolumn{3}{c|}{ Cu w \% } \\
\cline { 2 - 6 } & grupa B & grupa A & grupa B & grupa A & Wr \\
\hline nałóg & I & II & 58,33 & 31,82 & 21,97 \\
\hline uzależnienie & II & II & 37,50 & 31,82 & 5,68 \\
\hline choroba & III & I & 35,42 & 36,36 & 0,94 \\
\hline przemoc & IV & VI & 29,12 & 12,50 & 16,62 \\
\hline alkohol & V & V & 20,83 & 18,18 & 2,65 \\
\hline problemy & V & IV & 20,83 & 22,73 & 1,90 \\
\hline patologia & VI & II & 16,67 & 31,82 & 15,15 \\
\hline agresja & - & III & - & 27,27 & 27,27 \\
\hline
\end{tabular}

Źródło: opracowanie własne. 
Zawarte w tabeli 3 dane pokazują wyraźne rozbieżności w obrębie językowego prototypu alkoholizmu u respondentek z poszczególnych grup. Okazało się, że w obu zbiorach materiału leksykalnego tylko jedno skojarzenie osiągnęło próg częstości użycia wynoszący 50,00\%. Jest to reakcja werbalna „nałóg”, która uzyskała najwyższą lokatę rangową wśród skojarzeń osób wywodzących się z rodzin bez problemu nadużywania alkoholu. Wymieniło ją $58,33 \%$ spośród nich. Natomiast na pierwszej pozycji rangowej wśród asocjacji podanych przez respondentki z rodzin z problemem alkoholowym znalazło się skojarzenie "choroba" $(36,36 \%)$. Stąd właśnie te skojarzenia stały się emblematami językowego obrazu alkoholizmu u respondentek z poszczególnych grup.

Ta rozbieżność wydaje się wskazywać na dwie kwestie. Pierwszą z nich jest wpływ na proces kojarzenia respondentek wywodzących się z rodzin dotkniętych problemem nadużywania alkoholu stosowania przez nie psychologicznej reguły fałszującej obraz rzeczywistości, która łączy się z bezwzględnym milczeniem na temat przeżywanych w rodzinie trudności (Kałdon, 2015, s. 98; Niewiadomska i Fel, 2015, s. 40), a także psychologicznych mechanizmów obronnych - wypierania i racjonalizacji (Frączek i Kofta, 1978, s. 648-649). Świadczy o tym fakt, że wśród reakcji werbalnych respondentek pochodzących z rodzin dotkniętych problemem alkoholowym żadna $z$ asocjacji nie osiągnęła progu $50 \%$ częstości użycia. Kolejną kwestią jest zakres wiedzy naukowej respondentek z rodzin dotkniętych problemem alkoholowym, dzięki czemu kategoryzują one alkoholizm jako chorobę (pierwsza pozycja rangowa).

Do następnego bloku zostały włączone asocjacje, które uzyskały częstość użycia wynoszącą $20 \%$ i jednocześnie zostały wymienione przez mniej niż $50 \%$ osób objętych badaniami. Respondentki z rodzin obarczonych problemem alkoholowym wymieniły sześć skojarzeń spełniających ten warunek. Z kolei te, w których rodzinach nie jest on nadużywany, podały ich pięć. Stąd ostatecznie w obrębie językowego prototypu alkoholizmu u osób z poszczególnych grup znalazła się jednakowa liczba asocjacji.

Udało się zauważyć, że w obrębie językowego prototypu alkoholizmu u osób objętych badaniami zaznaczają się dwa zakresy znaczeniowe. Pierwszy z nich odnosi się do istoty alkoholizmu („nałóg”, „uzależnienie”, „choroba” oraz „patologia" - jedynie wśród reakcji werbalnych respondentek z rodzin z problemem alkoholowym ${ }^{5}$ ), kolejny - ukazuje konsekwencje alkoholizmu (,problemy”, „przemoc” - w grupie respondentek z rodzin bez nadużywania alkoholu ${ }^{6}$, „agresja” - w grupie osób z rodzin dotkniętych nadużywaniem alkoholu ${ }^{7}$ ).

Na szczególną uwagę zasługuje asocjacja „alkohol”, która znalazła się w obrębie językowego prototypu alkoholizmu u respondentek z obu grup. Uplasowała się

5 Reakcja werbalna „patologia” osiągnęła w grupie respondentek z rodzin, w których nie pojawił się problem nadużywania alkoholu, częstość użycia wynoszącą tylko 16,67\% i nie znalazła się w obrębie ich językowego prototypu alkoholizmu.

6 Skojarzenie „przemoc” uzyskało w grupie osób wywodzących się z rodzin dotkniętych problemem nadużywania alkoholu częstość użycia wynoszącą jedynie 12,50\% i nie znalazło się w obrębie ich językowego prototypu alkoholizmu.

7 Asocjacja „agresja” nie pojawiła się w materiale leksykalnym otrzymanym od respondentek z rodzin nieobciążonych problemem nadużywania alkoholu. 
ona na jednakowej - piątej - pozycji rangowej. Jednakże częstość jej użycia przez osoby z poszczególnych grup okazała się odmienna. Respondentki z rodzin dotkniętych problemem alkoholowym wymieniały ją nieco rzadziej niż osoby z rodzin, w których alkohol nie jest nadużywany. Podobną sytuację można dostrzec w odniesieniu do skojarzenia „uzależnienie”, które zajęło również jednakową - drugą - pozycję rangową w zbiorach asocjacji uzyskanych od respondentek z poszczególnych grup. I w tym wypadku było ono rzadziej wymienianie przez osoby, w których rodzinach jest nadużywany alkohol. Wydaje się to świadczyć o wpływie na przebieg procesu kojarzenia u respondentek wywodzących się z rodzin dotkniętych problemem nadużywania alkoholu przekonania o konieczności ochrony wizerunku swojej rodziny, a także głęboko zakorzenionego wstydu przed innymi osobami (Kałdon, 2015, s. 98; Niewiadomska i Fel, 2015, s. 40).

Warte uwagi jest również to, że asocjacja „choroba”, która zajęła odmienne pozycje rangowe $\mathrm{w}$ obrębie językowego prototypu alkoholizmu u respondentek z obu grup, osiągnęła zbliżoną częstość użycia w poszczególnych zbiorach materiału badawczego. Wskaźnik ją różnicujący wynosi zaledwie $0,94 \%$. Świadczy to o społecznie, kulturowo i edukacyjnie uwarunkowanym odczuwaniu istotności tego elementu w językowym obrazie alkoholizmu przez respondentki z obu grup.

Interesujące jest to, że skojarzenie „przemoc” uzyskało odmienne pozycje rangowe w materiale leksykalnym otrzymanym $w$ różnych grupach. Było ono częściej wymieniane przez osoby z rodzin, których członkowie nie nadużywają alkoholu. Wartość wskaźnika różnicującego częstość jego użycia wynosi aż 16,62\%. Natomiast asocjacja „agresja”, która uplasowała się na trzeciej pozycji rangowej wśród reakcji werbalnych uzyskanych od osób wywodzących się z rodzin dotkniętych problemem alkoholowym, nie pojawiła się wśród skojarzeń respondentek pochodzących z rodzin, w których nie ma takiego problemu. Przyczyn tej sytuacji można upatrywać we właściwościach reprezentacji poznawczej kształtującej się u respondentek z poszczególnych grup pod wpływem wiedzy, przekonań, wyobrażeń, a także obrazu siebie i otaczającego świata, które są prawdopodobnie modelowane przez doświadczanie nadużywania alkoholu przez członków rodziny.

\section{Podsumowanie}

Analiza materiału badawczego otrzymanego w związku z ekspozycją słów-bodźców nałóg i alkoholizm pozwoliła dostrzec właściwości ich językowego prototypu u osób objętych badaniami. Okazało się, że różnice ilościowe w zakresie reakcji werbalnych podawanych przez respondentki z poszczególnych grup w odniesieniu do konkretnych słów-bodźców są nieznaczne. Wynika stąd, że obecność w środowisku rodzinnym osoby nadużywającej alkoholu nie wpływa w istotny sposób na ich ilość wymienianą przeciętnie przez osoby objęte badaniami.

Znamienne, że językowy prototyp nałogu jest zbieżny ze względu na zawartość treściową u respondentek z poszczególnych grup. Wypełniają go asocjacje wskazujące zarówno na naturę alkoholizmu, jak i najpowszechniejsze rodzaje substancji uzależniających. Udało się zauważyć, że większość tych skojarzeń 
zajmuje równoległe pozycje rangowe, zaś tylko nieliczne spośród nich ulegają pewnym przesunięciom poza jego obręb. Warte odnotowania jest to, że w poszczególnych grupach respondentek reakcje te osiągnęły różną częstość użycia, która wskazuje na odmienne odczuwanie przez nie istotności konkretnych elementów w językowym obrazie nałogu.

Również językowy prototyp alkoholizmu u respondentek z poszczególnych grup ma zbliżony zakres znaczeniowy. Skojarzenia go wypełniające wskazują nie tylko na naturę alkoholizmu, ale i na jego konsekwencje. Jednakże osiągnęły one nie tylko odmienną częstość użycia, ale zajęły też różne pozycje rangowe u respondentek z poszczególnych grup.

Podsumowując, można stwierdzić, że nałóg i alkoholizm są takimi elementami językowego obrazu świata respondentek, których profil jest utrwalony przez oddziaływania społeczno-kulturowe i edukacyjne. Natomiast częstość użycia, którą osiągnęły asocjacje budujące językowy prototyp tych elementów rzeczywistości wskazuje na subiektywnie odczuwaną przez respondentki z poszczególnych grup istotność konkretnych jego aspektów.

Spostrzeżenia te pokazują, że zawartość językowego prototypu poszczególnych elementów świata jest uwarunkowana społecznie i kulturowo, ale również - uzależniona od zakresu osobistego doświadczenia egzystencjalnego konkretnych użytkowników tego języka naturalnego.

\section{Bibliografia}

Anusiewicz J., Dąbrowska A., Fleischer M. (2000), Językowy obraz świata i kultura. Projekt koncepcji badawczej, [w:] A. Dąbrowska i J. Anusiewicz (red.), Język i Kultura 13. Językowy obraz świata i kultura, Wydawnictwo Uniwersytetu Wrocławskiego, Wrocław, s. 11-44.

Bartmiński J. (2012), Językowe podstawy obrazu świata, Wydawnictwo UMCS, Lublin.

Cudak H., Dysfunkcje rodziny i jej zagrożenia opiekuńczo-wychowawcze (2011), „Pedagogika Rodziny" $1 / 2$, s. 7-14.

Frączek A., Kofta M. (1978), Frustracja i stres psychologiczny, [w:] T. Tomaszewski, Psychologia, PWN, Warszawa, s. 628-678.

Grabska M. (2000) Asocjacyjny portret mężczyzny, [w:] „Słowa, słowa, słowa”... w komunikacji językowej, Fundacja Rozwoju Uniwersytetu Gdańskiego, Gdańsk, s. 335-348.

Jedliński R. (2000), Językowy obraz świata wartości w wypowiedziach uczniów kończących szkołę podstawową, Wydawnictwo Naukowe Akademii Pedagogicznej, Kraków.

Kałdon B. (2015), Wybrane aspekty funkcjonowania dorosłych dzieci alkoholików w życiu społecznym (2015), „Seminare. Poszukiwania Naukowe” 36(3), s. 95-106.

Kurcz I. (2000), Psychologia języka i komunikacji, Wydawnictwo Naukowe „Scholar”, Warszawa.

Maćkiewicz J. (1999), Wyspa - językowy obraz wycinka rzeczywistości, [w:] J. Bartmiński (red.), Językowy obraz świata, Wydawnictwo UMCS, Lublin, s. 193-206.

Miśkowicz M. (2013), Problemy współczesnej rodziny w dobie promowania wartości prorodzinnych, „Pedagogika Rodziny” 3(1), s. 111-128.

Młyński J. (2012), Wsparcie rodziny - analiza w aspekcie pracy socjalnej, „Studia Socialia Cracoviensia" 1(6), s. 127-142.

Niewidomska I., Fel S. (2015), Formy przystosowania młodzieży w rodzinie z problemem alkoholowym, „Zeszyty Naukowe KUL” 59, nr 4(232), s. 39-50. 
Ożdżyński J. (1995). Perspektywa kognitywna w badaniach nad językiem dzieci i młodzieży, [w:] J. Ożdżyński (red.), Językowy obraz świata dzieci i młodzieży, Wydawnictwo Naukowe WSP, Kraków, s. 32-65.

Rudkowska G. (1998), Osobowość: koncepcje, struktura, rozwój, [w:] W. Pilecka, G. Rudkowska, L. Wrona (red.), Podstawy psychologii. Podręcznik dla studentów kierunków nauczycielskich, Wydawnictwo Naukowe Akademii Pedagogicznej, Kraków, s. 283-319.

Woodworth R.S., Schlosberg H. (1963), Psychologia eksperymentalna, t. I, przeł. A. Lewicki, E. Vielerose, PWN, Warszawa.

Zalas K. (2011), Rodzina z problemem alkoholowym, „Prace Naukowe AJD. Pedagogika” 20, s. $285-303$.

\section{Abstract}

Alcohol abuse by a family member is one of the factors responsible for the development of this dysfunction. When present in a family environment, this issue has a deforming effect on the other members' perception and interpretation of reality. Hence, the image of themselves and the world around them which forms in their minds is often inadequate and false. Therefore, the question arises of whether alcohol abuse by a family member can be a factor modelling the linguistic image of the adult world.

The answer to this question can be sought in the results of an association experiment conducted among people from families affected by alcohol abuse and from those unaffected by it, using stimuli words addiction and alcoholism.

It was observed that the prototype of the linguistic image of addiction is very similar, both because of its denotation in female respondents in individual groups, and because of the ranking positions occupied by its constituent associations. However, the frequency of the use of specific associations was different for individual groups of respondents. This indicates that they perceive the significance of specific elements in the linguistic image of addiction differently. It also appears that that prototype of the linguistic image of alcoholism has a similar denotation. However, the associations which constitute it are not only used with different frequency, but they also occupied different ranking positions in replies by female respondents in different groups.

In conclusion, the study suggests that addiction is an element of the linguistic image of the world that largely depends on socio-cultural and educational impact. On the other hand, the linguistic image of alcoholism in the group of respondents is susceptible to the modelling effect of the presence of a family member who abuses alcohol.

Keywords: linguistic image of the world, family, alcohol abuse, association experiment 